\title{
Cytotoxic Activity of Achillea coarctata Poir. Extract ${ }^{\dagger}$
}

\section{Sevil Albayrak 1,* and Nurcan Silahtarlığlu ${ }^{2}$}

1 Biology Department, Science Faculty, Erciyes University, Kayseri 38000, Turkey

2 Graduate School Natural Applied Science, Erciyes University, Kayseri 38000, Turkey; nurcan3889@gmail.com

* Correspondence: salbayrak@erciyes.edu.tr; Tel.: +90-352-207-6666

+ Presented at the 2nd International Conference on Natural Products for Cancer Prevention and Therapy, Kayseri, Turkey, 8-11 November 2017.

Published: 17 November 2017

\begin{abstract}
Achillea L. (Asteraceae) is a traditional medicinal herb which contains different phenol and flavonoid compounds that are responsible for Achillea pharmacological effects. Turkey is one of the most important centers of diversity for the genus Achillea in the world. The aim of this research was the investigation of the cytotoxic activity of $A$. coarctata Poir. extract on a human breast cancer cell line (MCF-7). The cytotoxic activity of the extract on the MCF-7 cell line and mouse embryo fibroblast cells (NIH/3T3) were evaluated by 3-(4,5-dimethyl thiazol-2-yl)-2,5-diphynyl tetrazolium bromide (MTT) assay. The extract has cytotoxic activity on MCF-7 cell line with IC50 values 37.39 and $33.98 \mu \mathrm{g} / \mathrm{mL}$ after 24 and $48 \mathrm{~h}$ treatments, respectively. The results showed that the extract inhibited significantly MCF-7 cell. Further investigation is required to assess the cytotoxic potential of the extract in cancer therapy, and to isolation and purification of bioactive compounds.
\end{abstract}

Keywords: Achillea coarctata; cytotoxic activity; MCF-7

Acknowledgments: This work was supported by the Research Fund of the University of Erciyes. Project number is FYL-2017-7077.

(C) 2017 by the authors. Licensee MDPI, Basel, Switzerland. This article is an open access article distributed under the terms and conditions of the Creative Commons Attribution (CC BY) license (http://creativecommons.org/licenses/by/4.0/). 